\title{
Impacts of Tsunami and Security Situations on Marine Fisheries of Kinniya, Trincomalee
}

\author{
M.S.M. Nafees, A.R.S.B. Athauda ${ }^{1}$ and U. Edirisinghe ${ }^{1}$ \\ Postgraduate Institute of Agriculture \\ University of Peradeniya \\ Peradeniya, Sri Lanka
}

\begin{abstract}
Kinniya is one of the 11 Divisional Secretary Divisions in Trincomalee district populated with more than 96\% of Muslims. Geographical location of Kinniya around Thampalakamam bay and Koddyar bay provides a lucrative livelihood for $13^{r d}$ of its total population via marine fisheries. Thampalakamam bay is a brackish water resource with diversified aquatic biota which facilitates coastal fisheries while the Koddyar bay facilitates offshore and deepsea marine fisheries. Significant irreparable reduction in fish production was observed from 2005 onwards, especially in Kinniya, irrespective of regrowth in fish production in other regions of Trincomalee district afterwards. Hence, a study was conducted with preliminary data collected through participatory appraisal with stakeholders of Kinniya fishing community to objectively test the root cause of continued reduction in fish catch. According to the study, associated location of Kinniya adjacent to Mullaitivu district facilitated the infiltration of terrorists into the natural harbour and military bases located in both bays. Preventive security measures imposed by the military against terrorists caused restrictions on Kinniya fishermen with regard to fishing time, fishing area and usage of motorized fishing fleet. Aftermath of these restrictions led to various biologically destructive livelihood activities inside and outside the two bays. Also, the effect of Tsunami in 2004 aggravated the already deteriorated livelihood of fisherfolks in Kinniya. Before these restrictions, Kinniya fishermen went in search of fish all around the two bays but at the moment they are waiting until fish come to their sites. This major change reduced the fish catch dramatically in Kinniya, especially due to overfishing, co-effects of civil war, location of harbour, anthropogenic effects and tsunami devastation. Ultimately, an environmentally sound and socially peaceful fishery of Kinniya was converted into environmentally and socially deteriorated fisheries.
\end{abstract}

\section{INTRODUCTION}

Sri Lanka's coastal fisheries contribute a greater share to the country's total marine fish production compared to offshore and deep sea production. In 2007, the country's coastal fish production was 150,000 metric tons (Fig. 1) which was about $60 \%$ of the total marine fish production and $52 \%$ of the total fish production in that year (NARA, 2007). According to Maldeniya (1997), marine fisheries contribute around $90-95 \%$ to the country's total fish production and their backbone is the coastal fisheries, which contributes $70-80 \%$ of the total marine fish production.

\footnotetext{
${ }^{1}$ Department of Animal Science, Faculty of Agriculture, University of Peradeniya, Peradeniya, Sri Lanka
} 
Sri Lanka's coastal zone which covers around $24 \%$ of the country's land area with about $32 \%$ of the 19 million people is a critical lifeline that anchors the country's social, economic and environmental developments (Fernando, 2002). Coastal inhabitants of Sri Lanka primarily engaged in exploiting resources closer to their settlement (Wijayaratne and Maldeniya, 2003) and fishing has been the main livelihood of large numbers of them (Nevil, 2005).

According to NARA (2007), out of nine provinces of Sri Lanka, Eastern Province consisting of Ampara, Batticaloa and Trincomalee districts provided around 13\% of the country's total marine fish production in year 2007. Around $17 \%$ of the total population of Eastern Province is a fisherfolk population comprising of 550 fishing villages with 62,420 active fishermen. Proportion of fisherfolk population is high in Trincomalee district compared to other two districts of Eastern Province. Around $22 \%$ of the total population of Trincomalee district is fisherfolk members while Ampara and Batticaloa districts consists of $13 \%$ and $17 \%$ of their total population respectively.

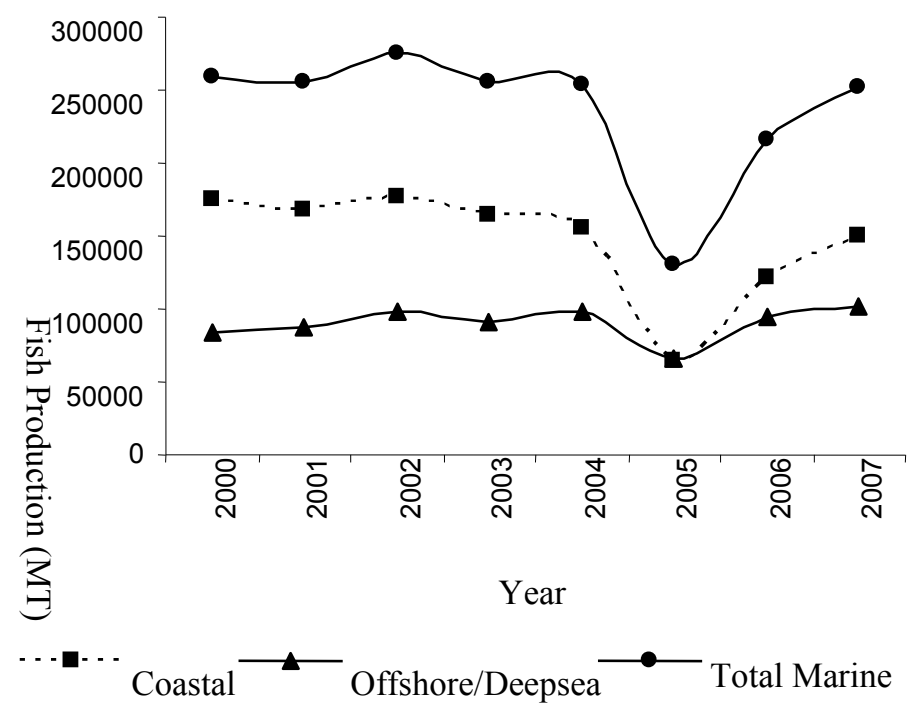

Fig. 1. Annual Marine Fish Production in Sri Lanka

Almost a steady level of fish production was shown by Trincomalee district from year 2000 up to 2004 while other two districts of the Eastern Province showed significant level of growth and decline in production (Fig. 2) during the same period of time (Fisheries Year Book, 2007 and Anon., 2007). Irrespective of civil war situation that existed in Eastern Province, significant level of drop in fish production was observed after Tsunami in 2004 (Fig. 2). Especially in Trincomalee district, the drop is still continuing at a lower level while the other two districts showed comparable growth in catch.

Trincomalee district is very popular due to its deepwater natural harbour, abundant fish resources, large marine fauna such as whales and dolphins (Rajasuriya et al., 2005) and also it is one of the multi-ethnic districts of Sri Lanka populated with Sinhalese, Muslims and Tamils. According to Korf and Singarayar (2002), the Sinhalese villages are mainly 
distributed in agricultural areas close to the interior of the country, while Muslim and Tamil villages are in close proximity to each other and mainly in the coastal strips.

Kinniya is one of the 11 Divisional Secretary (DS) Divisions of Trincomalee district having around $18.5 \%$ of district's total population who are mainly engaged in agricultural activities and marine fisheries for their livelihood. Out of six severely affected DS Divisions of Trincomalee district, around $37 \%$ of human death and $30 \%$ of land ownership losses were recorded in Kinniya DS Division due to Tsunami devastation in December 2004 (Anon., 2007). These figures show the degree of livelihood loss of coastal dwellers in Kinniya especially in fisheries activities. According to the Statistical Hndbook of Trincomalee District (2005), the total marine fish production dropped from 190,000 kg in 2004 to 85,000 $\mathrm{kg}$ in 2005. Above facts reiterate an urgent need to study the actual facts on lower catch in Kinniya and to suggest environmentally friendly solutions in order to sustain the livelihood of the coastal communities of Kinniya.

Therefore, a preliminary survey was conducted to objectively test the existing facts, which have resulted in decreased marine fish production in Kinniya.

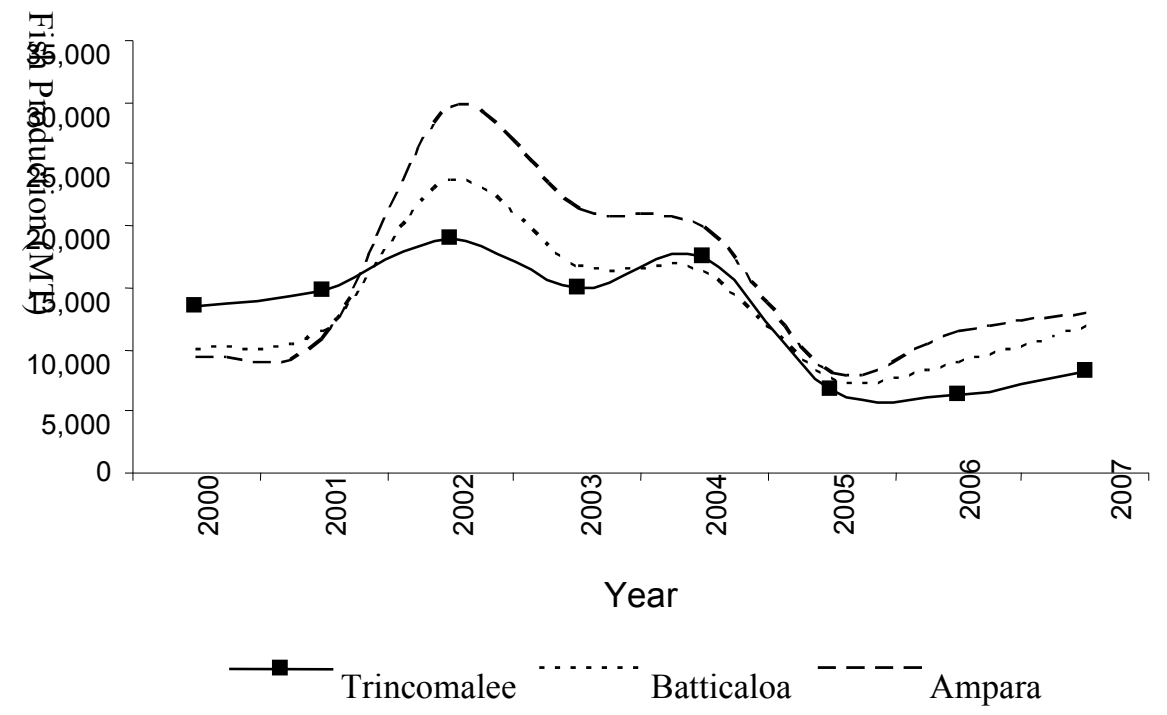

Fig. 2. Annual marine fish production in Eastern Province of Sri Lanka

\section{MATERIALS AND METHODS}

Using stratified random sampling, a questionnaire survey was conducted through participatory appraisal method. Ten fishermen were randomly selected from each of the twelve fishing villages of Kinniya which include both Thampalakamam and Koddyar bay in order to collect information regarding their traditional fishing activities, resource use patterns, resource use conflicts, current status of fishing and prevailing hurdles faced by them. An interview was conducted with officers, a relevant authorities viz. Fisheries Inspectors, Audits, Regional Environmental Officer and Planning Officer of Kinniya in order 
to collect data on aquatic resources. The collected data were analyzed by using MS Excel and SPSS statistical software.

\section{RESULTS AND DISCUSSION}

\section{Kinniya at a glance}

Kinniya has an extent of $165 \mathrm{~km}^{2}$ land area located about $20 \mathrm{~km}$ from the town of Trincomalee and $240 \mathrm{~km}$ from the national capital Colombo. Being located in the vicinity of Trincomalee harbour, Kinniya was badly devastated by the massive Tsunami in 2004 .

According to the Department of Census and Statistics of Sri Lanka, there are 31 Grama Niladhari (GN) Divisions in Kinniya having a population of 61,558 with approximately $1: 1$ sex ratio. Around $96 \%$ of the residents are Sri Lanka Moors, while 4\% are Sri Lanka Tamils. About 55\% of the population is over 18 years (Anon., 2007).

Geographical nature of Kinniya facilitates fisheries activities with the possession of two important fishing grounds such as Thampalakamam bay in northern boundary of Kinniya and Koddyar bay in eastern boundary (Fig. 3). Traditionally, these two bays have been supporting the livelihood of coastal dwellers of Kinniya, next to agriculture.

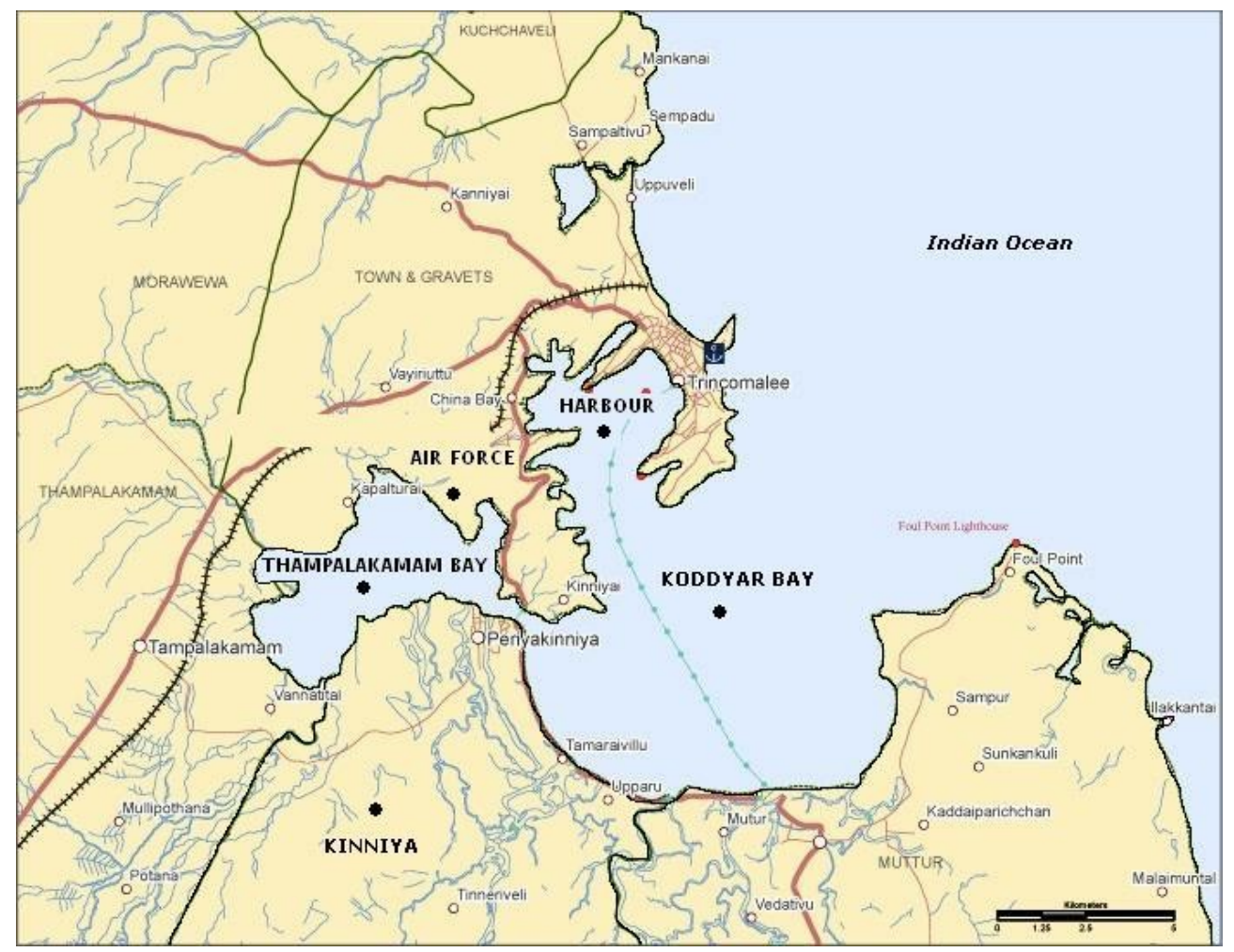

Fig. 3. Location of Kinniya, Thampalakamam bay, Koddyar bay, Air Force Base and harbour in Trincomalee District

\section{Marine fisheries resources of Kinniya}


There are two marine water fishing grounds viz. Thampalakamam Bay and Koddyar bay in Kinniya. Almost one-third of the peripheral line of Thampalakamam bay is lined by part of the Kinniya coastal area while another one-third touches the Sri Lanka Air Force base (China Bay Air Force base) which is opposite to the Kinniya village (Fig. 3). This Thampalakamam bay is an estuary connected with inland freshwater bodies of Kinniya. As such, it has diverse aquatic resources viz. Mugil cephalus, Chanos chanos, Lates calcarifer, Acanthopagrus sp., Siganus sp., shrimp, crab, clam, mussel, oyster, cockle and mangroves. The estuary is an interface between freshwater and marine ecosystems with highly variable salinity and rich nutrient content often utilized as a rich fishing ground (Yap, 2001). Most of the brackish water bodies of Sri Lanka have been used as traditional fishing grounds by small scale fishing communities (Senarath, 1998). Natural harbour of Sri Lanka is enclosed by Koddyar bay which is directly connected with Indian Ocean (Fig. 3). Koddyar bay fishermen widely use the adjacent Indian Ocean areas for offshore and deepsea fisheries.

\section{Fishermen of Kinniya}

According to the Kinniya Fisheries Co-operative Society's data, there are 12 fishing villages in Kinniya registered under 12 Fisheries Co-operative Societies consisting of around 5,200 fisher-folk families. Of them around 3,500 are full-time fishermen including about 1000 fishermen from Thampalakamam bay fishing community under 7 fishing villages while others from Koddyar bay fishing community of Kinniya. Out of 31 GN Divisions of Kinniya, 11 Divisions with 699 persons engaged in fisheries were affected by Tsunami in 2004 . Immediately after Tsunami, the number was reduced to 186 persons (Anon., 2005) but it has increased rapidly afterwards. It was observed that the new membership was due to the registration of non-fishery people in the Fisheries Co-operative Societies in order to get assistance from NGOs since they lost their assets which were utilized for their livelihood activities. It led to malfunctioning of Fisheries Co-operative Societies in Kinniya, where a significant number of fishermen have not registered in the society.

\section{Mode of fishing in Kinniya in the past}

Around one and half decades back, fishing was done all around the two bays at any time. In Thampalakamam bay more than $90 \%$ of the fishermen did coastal fishing with the use of artisanal wooden craft (Thony) and handlines, while others used cast nets, gill nets and traps. Maldeniya (1985) reported that the large numbers of small-scale fishermen in the country use handlining, an ancillary method of fishing, with non-mechanized traditional crafts. Coastal fisherfolks of this bay had achieved self sufficiency in fish production which covered their food, livelihood and future savings. In addition to fish, there was harvesting of clam, mussel, cockles and oyster to compensate the low fish production during some seasons. But, irrespective of particular seasons, fishermen harvested products of Thampalakamam bay throughout the year. Mainly, fish and other harvests were sold directly to fish mongers or sold at niche level.

In Koddyar bay, less than $5 \%$ of the fishermen used handline and artisanal wooden crafts while others used gillnet with outboard engined fiber glass boats for offshore and deep sea fisheries and beach seine for coastal fisheries. Handline was used mainly for seasonal fishing, particularly during the Lepturacanthus savala (ribbonfish) season. There were regular cyclic seasons each year for some fish species mainly Thunnus sp. (soorai), Clupea harengus (keeri), Amblygaster sp. (saalai), Sardinella sp. (soodai) and Stolephorus sp. 
(neththali). During those seasons, fishermen were catching abundantly those fish species continuously for certain months. Thus the fish prices reduce to very low levels in local markets. In order to keep the fish price constant, dried fish preparation was popular during this season and also excess fish were taken to Colombo markets in the form of iced fish as well as dried fish. It was also noted by Northeast Secretariat on Human Rights (NESOHR), (2006), that the bay area around Trincomalee harbour is a rich fishing ground where there is a season for a particular species of fish known as soodai (Sardinella sp.).

Peak fish production period of Kinniya is February to October. Especially during rainy season, the harvest of shrimps and crabs is high in Thampalakamam bay. Around 8,000 kg of fish is produced per day from both bays of Kinniya and only around 38\% of that production is consumed locally, while the rest of the production is sent to Colombo every day.

\section{Root causes associated with current fishing trends in Kinniya}

\section{Restriction imposed on fishing time and fishing area by Sri Lanka Navy (SLN)}

A decade back, there were two major terrorist attacks in a one year interval against SLN and Air Force by LTTE in Koddyar bay and Thampalakamam bay respectively. Since there is a mandate to protect the natural harbour and the military bases, the government of Sri Lanka imposed restriction on Kinniya fishermen. Accordingly, the first restriction which was imposed on Koddyar bay fishermen by SLN is the prohibition on usage of outboard engined boats, limitation on fishing area and ban on night fishing, but in Thampalakamam bay no restrictions were imposed. Anyway, this restriction affected the offshore and deep sea fisheries and reduced the fish production significantly. It was reported by Kulathunga and Jayasinghe (1997) that the introduction of inboard motorization of boats in Sri Lanka contributed to the increased fish production from subsistence level to commercial level. One year later, the second restriction was imposed mainly on Thampalakamam bay fishermen in that the fishermen were restricted to a limited area during day time only.

In the course of time, Kinniya fishermen gradually started to use small mesh size bottom set gillnets in order to increase the catch within the limited time period in order to sustain their livelihood. As such, more than $80 \%$ of Thampalakamam bay fishermen now use the small mesh size nylon bottom set gillnets which sweep all the juveniles of fish, shrimps, crabs and molluses and broodfish and only a few are using handlines. In Koddyar bay, offshore and deepsea fisheries are now restricted to mainly coastal fisheries and a little offshore fishery with the use of artisanal crafts with handlines and beach seines, which ultimately affected the livelihood of Kinniya fisherfolk due to low catch.

Particularly in Thampalakamam bay, handline fishermen accuse nylon net fishermen because they sweep most of the fishe within the allocated time period and destroy some molluscs especially oyster, clam and mussel, which are used as bait by handline fishermen. In addition, the nylon net fishermen use the handline fishermens' fishing point in Thampalakamam bay as an index of rich fishing ground and put their net around them. As a result, significant inequity in catch between handline fishermen and nylon net fishermen has been observed, which has led to conflicts among them. Apart from the usage of small mesh size gillnets some fishermen use dynamite to exploit the coastal fish resources, which kills all the aquatic fauna irrespective of their developing stages. 
Blast fishing is the most damaging fishing practice in Trincomalee (Rajasuriya et al., 2005) and coastal fisheries including shrimp and lobster which suffer from declining catch per unit effort (CPUE) due to overfishing done by biologically destructive fishing gear (Kulathunga and Jayasinghe, 1997), which cause irreparable damage to the natural habitat (Edirisinghe, 2003).

\section{Destruction of mangrove vegetation}

Aftermaths of military restrictions on fisheries of Kinniya boosted some poor fisherfolks to fell the mangrove vegetation found right along the coastal line of Thampalakamam bay for selling as mangrove poles and fuel woods in order to compensate their livelihood loss. But, the destruction of mangroves further reduced the aquatic biodiversity of this bay since the breeding and feeding sites of important fish, shrimp and crab species were destroyed. According to the FAO (2007), mangrove forests which provide services to humans, including breeding, spawning, hatching and nursery grounds for marine and pelagic species, and livelihoods for human communities are considered highly threatened.

\section{Tsunami devastation}

In December 2004 Tsunami devastation caused severe loss to wealth, habitats, fishing gear, fishing crafts and caused human deaths of coastal communities of Kinniya. These losses further aggravated the lower fish production in Kinniya caused by the military restriction and natural habitat degradation. According to the FAO (2007), fisheries resources and ecosystems have generally not been significantly impacted by the Tsunami in Sri Lanka, though there are some local cases of effects but they were already severely depleted prior to the Tsunami due to unsustainable fishing practices, environmental degradation and overfishing.

However, in the case of Kinniya fisheries, production has come down to very low levels, which further directs fishermen to carryout illegal fishing in unsustainable manner. At present, the Kinniya's demand for fish is fulfilled by outside fish productions such as fish from Kuchchaveli and Trincomalee towns.

\section{Suggestions for the future improvement in fisheries of Kinniya}

Strengthening of Fisheries Co-operative Societies through reshaping their activities is important in order to refurbish the coastal fisheries of Kinniya. Since the local residents are the users, the management of coastal resources should be community-based with a comanagement strategy, and their involvement in the planning and implementation of coastal resource management projects and sharing in the benefits of the interventions will contribute to the success of coastal conservation measures, especially preventing overfishing and usage of small mesh size and replanting mangroves.

Negotiation with the SLN through politicians in order to increase the fishing time and to use outboard engine boats will upgrade the livelihood of coastal communities of Kinniya. An indepth study on available fisheries resources should be carried out in both bays in order to exploit the resources in a sustainable manner.

\section{CONCLUSIONS}


Adverse effect of prevailing civil war situations in Kinniya necessitated the implementation of security regimes in Koddyar bay and Thampalakamam bay in order to sustain the country's dignity by protecting the natural harbour, SLN base and air force bases located in those bay areas from terrorist attack. This security campaign caused pressures on fisheries of Kinniya for the last ten years viz. restrictions on fishing time and fishing area and prohibition on the usage of engine boats which ultimately led to livelihood redundancy of coastal communities of Kinniya. The livelihood loss of Kinniya fisherfolks was further aggravated due to poor fish catch as a result of illegal fishing, mangrove destruction and effect of Tsunami devastation.

This study clearly indicates that the root cause for the low fish production and continued livelihood deterioration of Kinniya fishing community as the co-effect of the geographical location of Kinniya, existing terrorist activities and coastal habitat degradation with the added effect of Tsunami devastation.

\section{ACKNOWLEDGEMENT}

This paper is based on the preliminary data collected from stakeholders of coastal resource users of Kinniya. Gratitude is hereby rendered to the fishermen and coastal community leaders of Kinniya and related government officers for their valuable information.

\section{REFERENCES}

Anonymous, (2005). Basic population information, Trincomalee District - 2007. Department of Census and Statistics - Sri Lanka.

Anonymous, (2007). Census of buildings and persons affected by the tsunami - 2004 . Kinniya DS Division, Trincomalee District. Dept. of Census and Statistics of Sri Lanka.

Edirisinghe, U. (2003). Sustainable aquatic resources management in the 21st century: Some important Issues. Trop. Agric. Res. and Ext. .l: 6.

FAO, (2007). An overview of the impact of the tsunami on selected coastal fisheries resources in Sri Lanka and Indonesia. Rap Publication 2007/19. Bangkok: FAO.

Fernando, S. (2002). Socio-economic issues in coastal fisheries management in Sri Lanka, p. 44. In: Coastal Fisheries Management, APO, Tokyo.

Korf, B., and Singarayar, R. (2002). Livelihoods, food Security and conflict in Trincomalee. Third CEPA/PIMU Poverty Symposium, Colombo, October 2002.

Kulathunga, A.A and Jayasinghe, S. (1997). Report of the regional workshop on the precautionary approach to fisheries management p.81. In Bay of Bengal Programme, Chennai, India, 1999. Medan, Indonesia.

Maldeniya, R. (1985). Status of demersal fishery in Sri Lanka: Development of small-scale fisheries. FAO-SIDA BOB P/WP/41. $30 \mathrm{p}$. 
Maldeniya, R. (1997). The coastal fisheries of Sri Lanka: Resources, exploitation and management, p. 72. In: Silvestre, G and Pauly, D. (Eds.). Status and management of tropical coastal fisheries in Asia, ICLARM Conf. Proc. 53, 208 p.

NARA (2007), Fisheries Year Book, National Aquatic Resources Research and Development Agency - NARA, Crow Island, Colombo - 15, Sri Lanka.

Nevil, N.B. (2005). Trash fish production and national fish feed requirements in Sri Lanka. Regional Workshop on Low Value and 'Trash Fish" In the Asia-Pacific Region, June 2005. Hanoi, Vietnam.

Northeast Secretariat on Human Rights (NESOHR). (2006). Fishing communities of northeast and ethnic fFactor. (www.nesohr.org)

Rajasuriya, A., Perera, N., and Fernando, M. (2005). Coral reefs degradation in the Indian Ocean (CORDIO) Status Report, 2005.

Senarath, R.M.U. (1998). Environmental management of brackish water aquaculture systems in Sri Lanka. M.Sc. Thesis, Asian Institute of Technology, School of Environment, Resources and Development, Bangkok, Thailand.

Statistical Handbook of Trincomalee District. (2005). Fisheries sector of Trincomalee district. Department of Census and Statistics, Sri Lanka.

Wijayaratne, B and Maldeniya, R. (2003). The role of fisheries sector in the coastal communities of Sri Lanka, p.629. In: Assessment, Management and Future Directions of Coastal Fisheries in Asian Countries. World Fish Cent. Conf. Proc. 67: 1 120p.

Yap, F. (2001). Utilizing Different Aquatic Resources for Livelihoods in Asia: A resource book. International Institute of Rural Reconstruction, International Development Research Centre, FAO, Network of Aquaculture Centers in Asia-Pacific and International Center for Living Aquatic Resources Management. 416 p. 